\title{
Sustainable Agriculture through Green Manuring: A Prospective Approach
}

\author{
S. Krishnaprabu* \\ Department of Agronomy, Faculty of Agriculture, Annamalai University, Annamalai Nagar, \\ Annamalai Nagar, Chidambaram 608 002, Tamil Nadu, India \\ *Corresponding author
}

\begin{tabular}{|c|}
\hline Keywords \\
\hline $\begin{array}{l}\text { Crop growth, Green } \\
\text { manuring, Humus } \\
\text { content, Soil organic } \\
\text { matter, Sustainable } \\
\text { agriculture }\end{array}$ \\
\hline Article Info \\
\hline $\begin{array}{l}\text { Accepted: } \\
18 \text { February } 2019 \\
\text { Available Online: } \\
10 \text { March } 2019\end{array}$ \\
\hline
\end{tabular}

\section{Introduction}

Organic farming is a natural way of farming without harming the environment and it is ecologically better system considering its environmental performance. Organic farming is followed in different ways in different countries and the many of such methods adopted are indigenous. Recently, Squallia and Adamkiewicz (2018) provided the evidence supporting potential GHG mitigation benefits associated with organic food production. Organic farming practices, focused on agro-ecological health, have long been centered on the idea that such approaches reduce resource intensity, improve soil health, reduce environmental burdens, and improve crop quality (Kuepper, 2010). Organic farming can play an important role for socio economic development and to make villages self-sustainable. Degradation of environmental quality and food safety concerns due to excess 
use of fertilizers promoted the organic farming in recent decades (Läpple and Cullinan, 2012). Organic farming is a method of farming system, which primarily aims at cultivating the land and raising crops in such a way, so as to keep the soil alive and in good health. In the Indian context organic farming is also termed as Javik Krishi (Singh et al., 2018). Mohan Kumar et al., (2017) concluded that the organic farming is more profitable than the conventional farming as well as organic farming keeps environment good. Growing medicinal and aromatic plants by the way of organic farming is gaining importance now-adays (Bijalwan, 2016). Application of biofertilizers is also one of the major organic farming approaches which is cost effective and eco-friendly (Nalawde and Bhalerao, 2015). Green manuring is one of the practices in organic farming concept where fast growing plants on the site into which incorporation of organic matter is needed, then turning into the soil while it is still fresh. The plant material used in this way is called a green manure. Green manuring is an easy method of improving soil structure and fertility. It also minimizes the cost.

\section{Green manuring}

There are two different kinds of green manuring practices followed widely, (i) on site (in situ) green manuring, and (ii) green leaf manuring. The first one is a method of growing short duration plants in the agricultural field itself and mulched onsite within 60-80 days of growth. While the second one is leaves or young shoots with leaves of shrubs or trees which are grown on borders or waste places are brought to the land, applied on the soil and mulched before crop cultivation. The practice of green manuring is mainly done to improve soil organic matter content whereby soil beneficial microbial activity is enhanced. More importantly, soil textural properties are much improved which favours germination and rooting of crop plants. Tamil Selvi and Arumugam (2017) summarized that the breeding approaches are also essential for improving the traits required for successful vegetable cultivation under organic farming system or in low-input conditions. The beneficial effects of green manuring are depicted in Figure 1.

\section{Plants used as green manures}

There are a number of plants which are used as green manure for enriching the soil (Table 1). The green manure plants may be herbaceous, shrubs or tree species which can produce leafy biomass in short duration. The herbaceous green manure plants include Crotalaria juncea, Vigna unguiculata and Cyamopsis tetragonaloba. Eichorrnia crassipes (aquatic), Trianthema portulacastrum, Cassia auriculata, Tephrosea purpurea and Calotropis gigantean are weedy plants which are being utilized as green manures. The leafy green manures used are obtained from the tree species such as Milletia pinnata, Azadirachta indica, Delonix regia, Peltophorum pterocarpum and Leucaena leucocephala. Some of the green manure plants are depicted in Figure 2.

\section{Nutrients in green manures and crop growth}

Apart from providing organic matter to the soil, green manuring provides nitrogen, phosphorus, potassium and other micro and macro-elements to the cultivated crop. Especially leguminous green manures like Gliricidia sepium, Milletia pinnata, Sesbania spp., Tephrosea purpurea and Crotalaria juncea supplies nitrogen in large quantities as these green manure plants are nitrogen fixing plants with the aid of rhizobium in their root nodules. The nitrogen content in these plants range from $1.6-3.5 \%$, phosphorus $0.30-1.0 \%$ 
and potassium $0.50-4.60 \%$ and hence the crops cultivated after green manure application greatly improves growth and yield. Organic farming resulted in significant increase in zinc content from 1.32 to $1.90 \mathrm{mg}$ $\mathrm{kg}^{-1}$, iron content from 9.38 to $11.38 \mathrm{mg} \mathrm{kg}^{-1}$ copper content from 1.19 to $1.28 \mathrm{mg} \mathrm{kg}^{-1}$ and $\mathrm{Mn}$ from 4.95 to $5.24 \mathrm{mg} \mathrm{kg} \mathrm{kg}^{-1}$ over conventionally managed soils (Sheoran et al., 2018).

Table.1 List of plants used as green manure crops

\begin{tabular}{|l|l|l|l|}
\hline Sl. No. & Common name & Botanical name & Family \\
\hline $\mathbf{1 .}$ & Dhaincha & Sesbania aculeata & Fabaceae \\
\hline $\mathbf{2 .}$ & Sunhemp & Crotalaria juncea & Fabaceae \\
\hline $\mathbf{3 .}$ & Sesbania & Sesbania speciosa & Fabaceae \\
\hline $\mathbf{4 .}$ & Manila agathi & Sesbania rostrata & Fabaceae \\
\hline $\mathbf{5 .}$ & Cowpea & Vigna unguiculata & Fabaceae \\
\hline $\mathbf{6 .}$ & Cluster bean & Cyamopsis tetragonoloba & Fabaceae \\
\hline $\mathbf{7 .}$ & Gliricidia & Gliricidia sepium & Fabaceae \\
\hline $\mathbf{8 .}$ & Pongamia & Milletia pinnata & Fabaceae \\
\hline $\mathbf{9 .}$ & Neem & Azadirachta indica & Meliaceae \\
\hline $\mathbf{1 0}$. & Gulmohar & Delonix regia & Caesalpiniaceae \\
\hline $\mathbf{1 1}$. & Peltophorum & Peltophorum pterocarpum & Caesalpiniaceae \\
\hline $\mathbf{1 2 .}$ & Subabool & Leucaena leucocephala & Mimosaceae \\
\hline $\mathbf{1 3 .}$ & Mexican sunflower & Tithonia diversifolia & Astraceae \\
\hline $\mathbf{1 4}$. & Water hyacinth & Eichorrnia crassipes & Pontederiaceae \\
\hline $\mathbf{1 5 .}$ & Trianthema & Trianthema portulacastrum & Aizoaceae \\
\hline $\mathbf{1 6}$ & Cassia & Cassia auriculata & Caesalpiniaceae \\
\hline $\mathbf{1 7 .}$ & Tephrosea & Tephrosea purpurea & Fabaceae \\
\hline $\mathbf{1 8}$. & Calotropis & Calotropis gigantea & Asclepiadaceae \\
\hline
\end{tabular}

Fig.1 The effects of green manuring

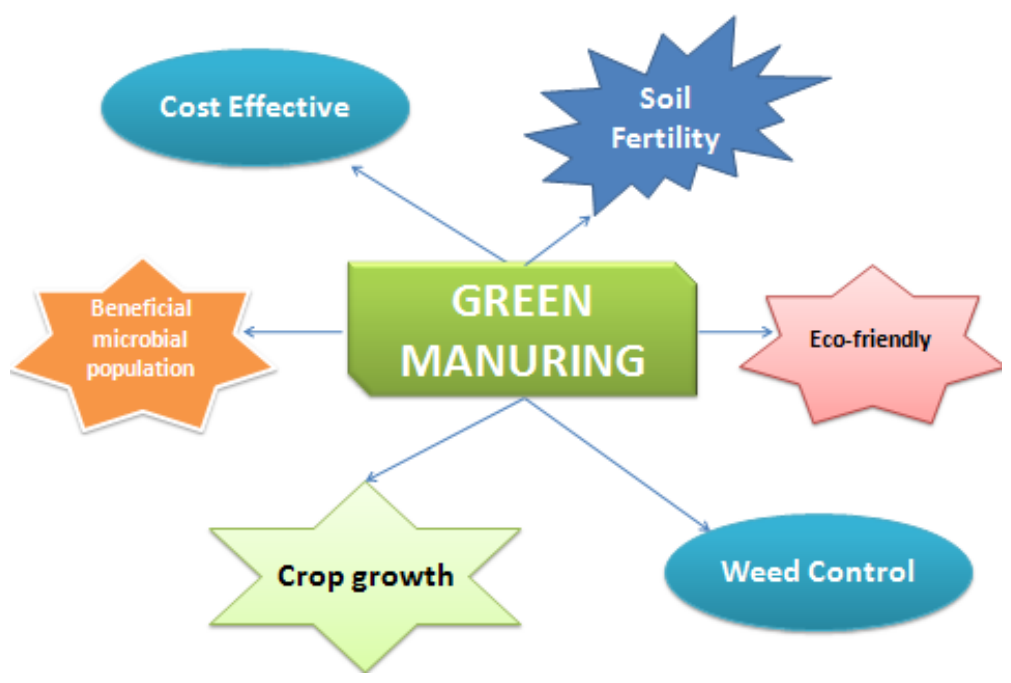


Fig.2 Some of the important green manure plants

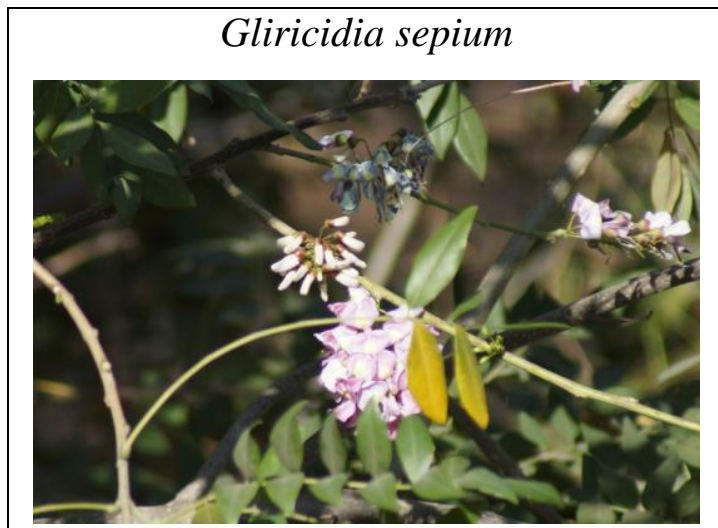

Tithonia diversifolia

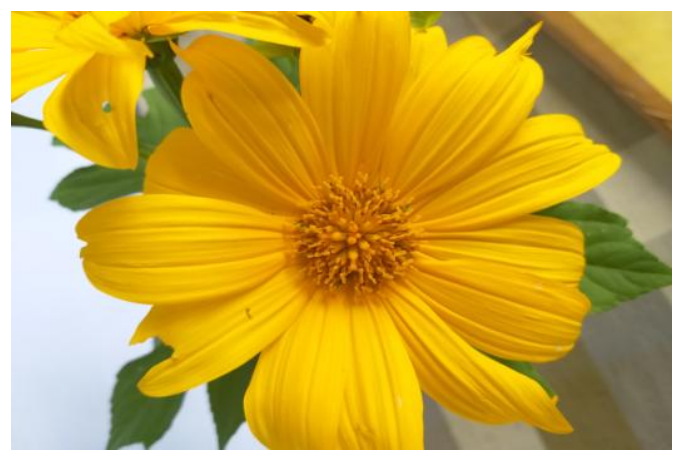

In a study, Srivastava (2015) concluded that the incorporation of leaves of $\mathrm{N}$-fixing multipurpose trees like Dalbergia sissoo and Cassia fistula significantly improve the biological basis of soil fertility and rice productivity in a short term in tropical dryland conditions. The study also recommended that for soil fertility amelioration geared to sustainable high rice productivity in tropical dryland agroecosystem, with least dependence upon chemical fertilizer input, the ecological soil fertility manipulation by application of high quality tree leaves holds great potential. In addition, the availability of organically bounded nitrogen through transformation in soil to the plant mainly depends on the population of microorganisms, which may be influenced by the application of inorganic fertilizers and organic manure (Puli et al., 2016). Also, Aiyelari (2016) reported that the application of $250 \mathrm{~kg} / \mathrm{ha}$ of organomineral

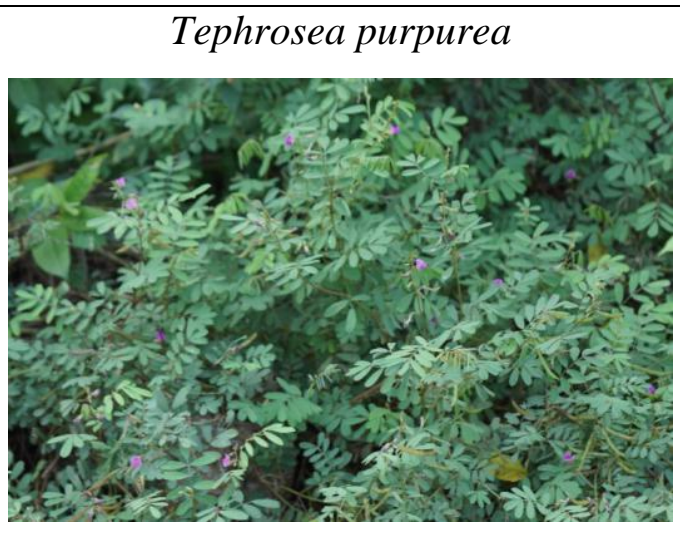

Milletia pinnata

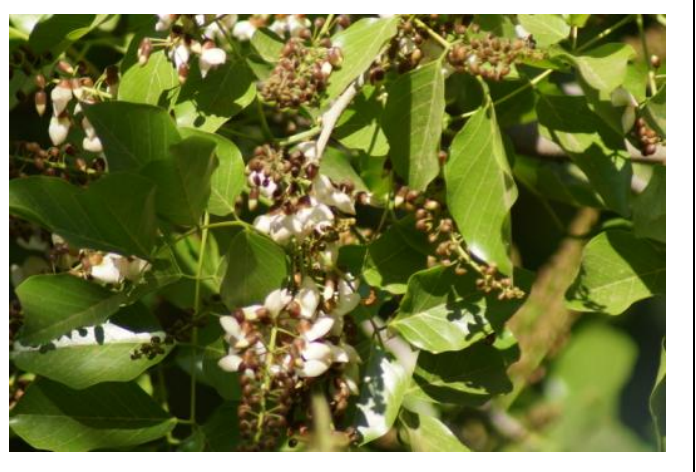

fertilizer produced overall highest growth and yield compared with other treatments suggesting that the use of organomineral and organic fertilizers should be encouraged in sugarcane production to obtain increase in the productivity of sugarcane. Apart from improved yields, organic farming can also serve to reduce expenditure with more profits (Madhukumar et al., 2018). In conclusion, considering the negative effects of chemical farming, organic farming with green manure plants is needed to be promoted. Since green manuring is cost effective, eco-friendly, enriches soil, and enhances plant growth and yield apart from improvements in soil organic matter content and microbial population. The studies clearly indicate that the green manuring is one possible way to achieve sustainability in agriculture which is an urgent need of the hour. 


\section{References}

Aiyelari, O. P., 2016. Effects of organic and inorganic fertilizers on the growth and yield of selected varieties of sugarcane (Saccharum officinarum). Int. J. Curr. Res. Biosci. Plant Biol. 3(8), 1-11.

Bijalwan, A., 2016. Organic cultivation of medicinal and aromatic plants: A case from Uttarakhand Himalaya, India. Int. J. Curr. Res. Biosci. Plant Biol. 3(4), $39-42$.

Kuepper, G., 2010. A Brief Overview of the History and Philosophy of Organic Agriculture, Kerr Center for Sustainable Agriculture, Poteau, OK.

Läpple, D., Cullinan, J., 2012. The development and geographic distribution of organic farming in Ireland. Irish Geog., 45 (1), 67-85.

Madhukumar, V., C. Seenappa, B.S. Lalitha, Sharanappa and Sanjay, M.T. 2018. Effect of Organic Farming Practices on Productivity, Quality and Economics of Chilli Hybrids in Central Dry Zone of Karnataka. Int. J. Curr. Microbiol. App. Sci. 7(02), 2877-2885.

Mohan Kumar, M., Adarsha, L.K., Singh, S. P., Likin Boppana, K., 2017. Economics of organic farming over conventional farming-A case study in Karnataka. Int. J. Curr. Microbiol. App. Sci. 6(11), 2810-2817.

Puli, M. R., Katkhar, R. N., Mitnala, J., Rao, B. R., 2016. Assessment of chemical and biological parameters in sorghumwheat cropping sequence under long term fertilization - A review. Int. J. Curr. Res. Biosci. Plant Biol. 3(6), 149159.

Sheoran, H. S., Phogat, V.K., Dahiya, R., Dhull, S., Kakar, R., 2018. Comparative effect of organic and conventional farming practices on micronutrient content in different textured soils of Haryana, India. Int. J. Curr. Microbiol. App. Sci. 7(4), 3399-3407.

Singh, K., Sunil Kumar, Pradhan, S., Patidar, O. K., 2018. Organic farming for sustainable and nutritional fruit production in India: A review. Int. J. Curr. Microbiol. App. Sci. 7(05), 30333039.

Squalli, J., Adamkiewicz, G., 2018. Organic farming and greenhouse gas emissions: A longitudinal U.S. state-level study. J. Clean. Prod. 192, 30-42.

Srivastava, R., 2015. Variation in total biological productivity and $\mathrm{N}$ uptake of tropical rice crop due to application of different $\mathrm{N}$ rich tree leaves as soil amendments. Int. J. Curr. Res. Biosci. Plant Biol. 2(2), 67-73.

Tamilselvi, N.A., Arumugam, T., 2017. Breeding approaches for sustainable vegetable production - A review. Int. J. Curr. Microbiol. App. Sci. 6(11), 28452860.

\section{How to cite this article:}

Kashish Walia, R.K. Aggrawal and Bhardwaj, S.K. 2019. Evaluation of Air Pollution Tolerance Index and Anticipated Performance Index of Plants and their Role in Development of Green Belt along National Highway-22. Int.J.Curr.Microbiol.App.Sci. 8(03): 2509-2513. doi: https://doi.org/10.20546/ijcmas.2019.803.297 